\title{
Pengaruh Pertumbuhan Ekonomi, Upah Minimum, dan Angkatan Kerja terhadap Tingkat Pengangguran di Provinsi Jambi
}

\author{
Ridho Kurniawan $^{1 *}$, Yulmardi ${ }^{2}$, Adi Bhakti ${ }^{3}$ \\ 1,2,3 Prodi Ekonomi Pembangunan, Fakultas Ekonomi dan Bisnis, Universitas Jambi
}

\begin{tabular}{|l|l|l|l|}
\hline Diterima: 04-11-2021 & Direvisi: 01-12-2021 & Disetujui: 18-12-2021 & Dipublikasi: 31-12-2021 \\
\hline
\end{tabular}

\begin{abstract}
This study aims to analyze the effect of population growth, inflation, unemployment rate, and human development index on the unemployment rate in Jambi Province. The data used is secondary data in the period $2001-2018$. The analysis tool uses multiple linear regression. The analysis results found that the average unemployment rate in Jambi Province during 2001 - 2018 was 4.45 percent. Simultaneously or partially, the unemployment rate in Jambi Province is influenced by economic growth, minimum wages, and the labor force.
\end{abstract}

Keywords: economic growth, minimum wages, labor force, the unemployment rate

\begin{abstract}
Abstrak
Penelitian ini bertujuan untuk menganalisis pengaruh pertumbuhan penduduk, inflasi, tingkat pengangguran dan indeks pembangunan manusia terhadap tingkat pengangguran di Provinsi Jambi. Data yang digunakan adalah data sekunder pada periode 2001 - 2018. Alat analisis menggunakan regresi linier berganda. Hasil analisis menemukan bahwa rata-rata tingkat tingkat pengangguran di Provinsi Jambi selama periode 2001 - 2018 adalah 4,45 persen. Baik secara simultan maupun parsial, tingkat pengangguran di Provinsi Jambi dipengaruhi oleh pertumbuhan ekonomi, upah minimum, angkatan kerja.
\end{abstract}

Kata kunci: pertumbuhan ekonomi, upah minimum, angkatan kerja, tingkat pengangguran

\section{Pendahuluan}

Tingkat pengangguran adalah salah satu indikator perekonomian. Perkembangan kondisi suatu negara dapat dilihat dari tingkat penganggurannya. Melalui angka pengangguran juga dapat dideteksi apakah terdapat ketimpangan atau kesenjangan distribusi pendapatan pada negara tersebut. Pengangguran terjadi karena pertambahan angkatan kerja yang tidak diimbangi dengan pertambahan lapangan pekerjaan yang memadai.

Sebagai salah satu negara berkembang, salah satu permasalahan yang dihadapi Indonesia adalah masalah pengangguran. Pengangguran merupakan masalah yang kompleks karena mempengaruhi sekaligus dipengaruhi oleh banyak faktor yang saling berinteraksi. Pengangguran yang tidak segera diatasi, selain menimbulkan kemiskinan juga dapat memicu berbagai kerawanan sosial.

Permasalahan lain dalam ketenagakerjaan di Indonesia adalah masalah upah yang rendah. Upah yang rendah secara langsung dan tidak langsung berpengaruh tingginya tingkat pengangguran (Mankiw, 2006). Upah yang rendah menyebabkan sebagian besar angkatan kerja memilih bekerja di sektor informal dibandingkan sektor formal dengan upah yang minim (Oetomo \& Silalahi, 2006).

\footnotetext{
* Penulis korespondensi

Email: ridhokurniawan3196@gmail.com
} 
Penetapan upah minimum yang dilakukan pemerintah memberikan pengaruh terhadap tingkat pengangguran. Semakin tinggi besaran upah yang ditetapkan oleh pemerintah maka hal tersebut akan berakibat pada penurunan jumlah orang yang bekerja pada negara tersebut. Teori penetapan upah dalam suatu pasar bebas sebenarnya merupakan kasus khusus dan teori nilai umum.

Upah merupakan kompensasi yang diterima pekerja. Upah merupakan hal penting baik bagi perusahaan maupun pekerja. Bagi perusahaan, upah merupakan biaya produksi yang harus ditekan seefisien mungkin. Bagi pekerja, upah merupakan sumber penghasilan bagi dirinya, keluarganya dan menjadi sumber pembelanjaan masyarakat. Tinggi rendahnya upah merupakan faktor penting yang menentukan taraf hidup masyarakat (Kaufman \& Hotchkiss, 2003). Ketetapan upah minimum telah diatur dalam Peraturan Pemerintahan Nomor 78 tahun 2015. Upah minimum terus meningkat setiap tahunnya pada seluruh wilayah di Indonesia.

Berdasarkan Badan Pusat Statistik terlihat bahwa upah minimum di Provinsi Jambi selama tahun 2015-2018 mengalami peningkatan. Upah minimum pada tahun 2015 sebesar Rp 1.710.000 dan pada tahun 2016 meningkat menjadi sebesar Rp1.906.650. Pada tahun 2017 meningkat kembali menjadi sebesar Rp2.063.000 dan pada tahun 2018 sebesar Rp2.381.941.

Hubungan jumlah angkatan kerja dengan jumlah pengangguran dijelaskan oleh teori penduduk optimum. Dijelaskan dalam teori penduduk optimum, jika terjadi kekurangan penduduk, produksi marginal akan lebih tinggi daripada pendapatan perkapita. Hal ini akan menyebabkan peningkatan pendapatan perkapita. Namun, jika penduduk sudah terlalu banyak, sesuai hukum hasil tambahan yang makin berkurang, produksi marginal akan mulai mengalami penurunan. Dalam kondisi ini, pertumbuhan pendapatan nasional dan pendapatan perkapita akan melambat (Sukirno, 2013).

Berdasarkan Badan Pusat Statistik terlihat bahwa angkatan kerja di Provinsi Jambi selama tahun 2015-2018 mengalami peningkatan. Angkatan kerja pada tahun 2015 sebesar 1.620.752 orang dan pada tahun 2016 meningkat menjadi sebesar 1.692 .193 orang. Pada tahun 2017 meningkat kembali menjadi sebesar 1.724 .633 orang dan pada tahun 2018 sebesar 1.790 .437 orang.

Kasus permasalahan pengangguran dirasa sudah cukup parah bagi pembangunan ekonomi khususnya di Provinsi Jambi. Beberapa indikator-indikator ekonomi sangat berpengaruh terhadap jumlah pengangguran. Berdasarkan hal tersebut, penelitian ini bertujuan untuk menganalisis pengaruh pertumbuhan ekonomi, upah minimum dan angkatan kerja terhadap tingkat pengangguran di Provinsi Jambi.

\section{Metode}

Data yang digunakan dalam penelitian ini adalah data sekunder Provinsi Jambi selama periode 2001 - 2018. Data bersumber dari BPS Provinsi Jambi. Alat analisis yang digunakan adalah model regresi berganda dengan persamaan sebagai berikut:

$$
\mathrm{TPG}_{\mathrm{t}}=\alpha+\alpha_{1} \mathrm{PE}_{\mathrm{t}}+\alpha_{2} \operatorname{LogUM}_{\mathrm{t}}+\alpha_{3} \operatorname{LogAK} \mathrm{K}_{\mathrm{t}}+\mathrm{e}
$$

$\begin{array}{ll}\text { Keterangan: } & \\ \text { TPG } & =\text { Tingkat Pengangguran } \\ \text { PE } & =\text { Pertumbuhan Ekonomi } \\ \text { UM } & =\text { Upah Minimum } \\ \text { AK } & =\text { Angkatan Kerja } \\ \text { Log } & =\text { Logaritma } \\ \boldsymbol{\alpha} 1, \boldsymbol{\alpha} 2, \boldsymbol{\alpha} 3 & =\text { Koefisien Regresi }\end{array}$




$$
\begin{aligned}
& \boldsymbol{\alpha} \quad=\text { Konstanta } \\
& \text { t } \quad=\text { Time Series } \\
& \mathrm{e} \quad=\text { Kesalahan pengganggu (stokastik) }
\end{aligned}
$$

\section{Hasil dan Pembahasan}

\section{Uji Normalitas}

Pengujian normalitas bertujuan untuk menguji distribusi data dari variabel-variabel penelitian. Model yang baik adalah model memiliki distribusi normal atau mendekati normal. Dalam penelitian pengujian normalitas menggunakan grafik histogram normalitas berikut:

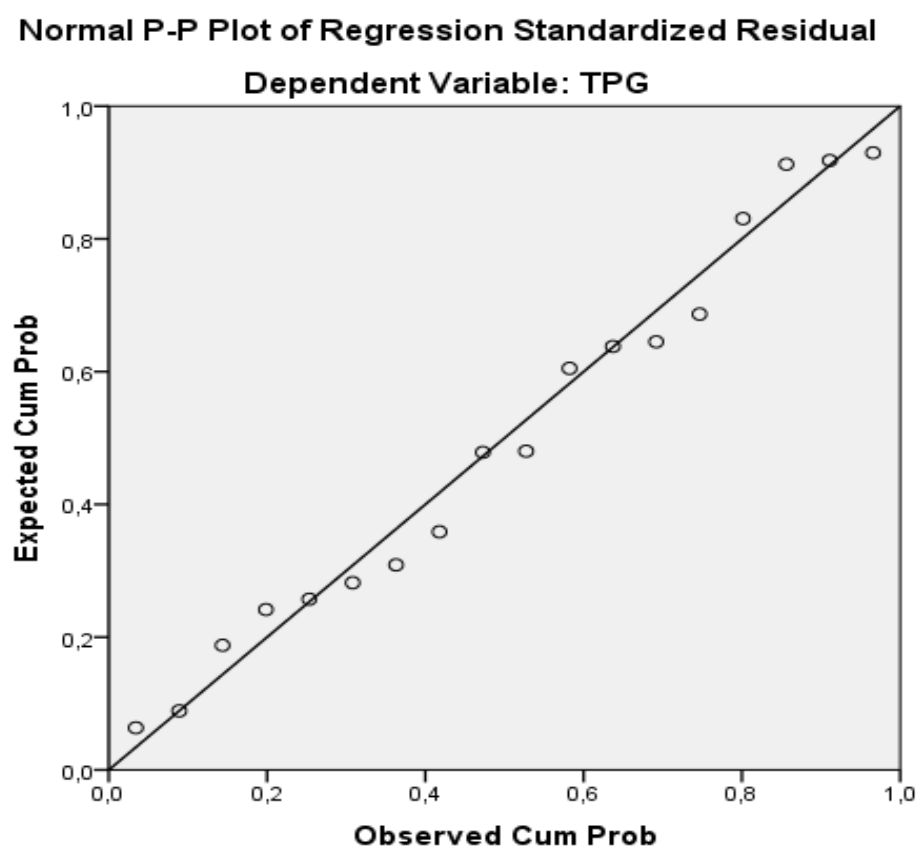

Gambar 1. Grafik Histogram Normalitas

Berdasarkan Gambar 1 terlihat bahwa model regresi berdistribusi normal, yang ditandai oleh sebaran data berada disekitar garis diagonal. Dengan demikian model regresi layak digunakan karena telah memenuhi asumsi normalitas.

\section{Uji Multikolinieritas}

Multikolinieritas menunjukkan hubungan yang kuat diantara beberapa atau semua variabel bebas pada model regresi. Untuk mendeteksi multikolinearitas dalam penelitian ini menggunakan nilai variance inflantion factors (VIF).

Tabel 1. Pengujian Asumsi Multikolinieritas

\begin{tabular}{llcc}
\hline & & \multicolumn{2}{c}{ Collinearity Statistics } \\
\cline { 3 - 4 } Model & & Tolerance & VIF \\
\hline 1 & (Constant) & & \\
& PE &, 936 & 1,069 \\
& LogUM &, 115 & 8,679 \\
& LogAK &, 113 & 8,817 \\
\hline
\end{tabular}

Sumber: Data diolah, 2020

Berdasarkan nilai VIF pada Tabel 1 terlihat tidak adanya korelasi yang kuat antara sesama variabel bebas. Nilai VIF lebih kecil dari 10, sehingga dapat disimpulkan tidak terdapat multikolinieritas diantara variabel bebas. 


\section{Uji autokorelasi}

Autokorelasi merupakan korelasi antara serangkaian observasi yang diurutkan menurut waktu dan ruang. Untuk mendeteksi gejala autokorelasi pada penelitian ini menggunakan Durbin-Watson Test. Berdasarkan perhitungan diperoleh nilai DW sebesar 1,649 .

Dengan menggunakan tabel statistik d dan derajat kepercayaan $95 \%(\alpha=0,05)$ jumlah observasi 18 serta jumlah variabel bebas 3 maka diperoleh angka $\mathrm{dl}=0,574 \mathrm{dan} \mathrm{du}=1,631$ sedangkan nilai untuk 4-dl = 3,426 dan 4-du = 2,369 dengan menggunakan uji statistik Durbin Watson dua ujung (two tailed) maka patokan yang digunakan adalah sebagai berikut:

$\mathrm{d}<\mathrm{dl}=$ berarti terdapat autokorelasi positif

$\mathrm{d}>\mathrm{dU}=$ berarti tidak terdapat autokorelasi positif

$(4-\mathrm{d})<\mathrm{dl}=$ berarti terdapat autokorelasi negative

$(4-d)>d U=$ berarti tidak terdapat autokorelasi negative

$\mathrm{du}<\mathrm{d}<(4-\mathrm{du})=$ berarti tidak terdapat autokorelasi

$\mathrm{dl}<\mathrm{d}<\mathrm{du}$ atau $(4-\mathrm{du})=$ berarti tidak dapat disimpulkan

Mengacu pada patokan tersebut dapat disimpulkan bahwa nilai DW yang diperoleh terletak pada daerah $\mathrm{d}>\mathrm{dU}$ atau tidak terdapat autokorelasi positif dalam penelitian ini.

\section{Uji heteroskedastisitas}

Pendeteksian heteroskedastisitas dalam penelitian dilakukan melalui pengamatan terhadap sebaran nilai-nilai residu, sebagaimana diberikan pada Gambar 2.

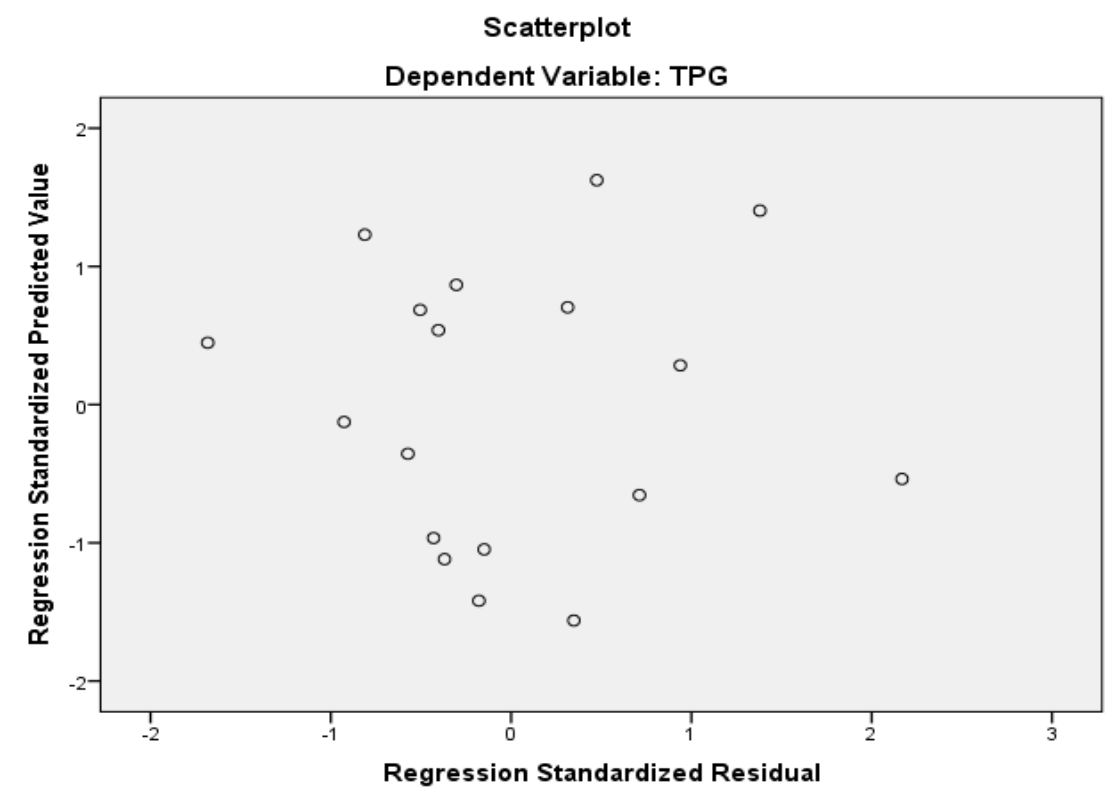

Gambar 2. Uji Heteroskedastisitas

Berdasarkan Gambar 2 terlihat bahwa tidak terdapat pola yang jelas dari sebaran nilai residu, sehingga dapat disimpulkan bahwa tidak terdapat masalah heterokedastisitas dalam model.

\section{Uji Hipotesis}

\section{Uji Simultan}

Pengujian simultan pengaruh variabel bebas terhadap variabel terikat menggunakan uji F. Hasil uji F diberikan pada Tabel 2. 
Tabel 2. Uji F statistik

\begin{tabular}{|c|c|c|c|c|c|c|}
\hline Model & & $\begin{array}{c}\text { Sum of } \\
\text { Squares }\end{array}$ & df & Mean Square & $\mathbf{F}$ & Sig. \\
\hline \multirow[t]{3}{*}{1} & Regression & 7,481 & 3 & 2,494 & 151,540 &, $000^{6}$ \\
\hline & Residual & 230 & 14 & ,016 & & \\
\hline & Total & 7,711 & 17 & & & \\
\hline
\end{tabular}

a. Dependent Variable: TPG

b. Predictors: (Constant), LogAK, LogUM, PE

Sumber: Data diolah, 2020

Berdasarkan Tabel 2 diperoleh signifikansi F-sig sebesar 0,000 lebih kecil dari 0,05. Artinya Ho ditolak dan Ha diterima. Dapat disimpulkan bahwa pertumbuhan ekonomi, upah minimum, angkatan kerja secara bersama-sama berpengaruh signifikan terhadap tingkat pengangguran di Provinsi Jambi selama periode 2001-2018.

\section{Koefisien Determinasi}

Koefisiensi determinasi menunjukkan ukuran besar/kecilnya pengaruh variabel bebas terhadap variabel terikat. Tabel 4 memberikan nilai koefisien determinasi model yang diteliti:

Tabel 3. Koefisien Determinasi

\begin{tabular}{llrrr}
\hline Model & R & R Square & Adjusted R Square & \multicolumn{2}{c}{$\begin{array}{c}\text { Std. Error of the } \\
\text { Estimate }\end{array}$} \\
\hline 1 &, $985^{\text {a }}$ &, 970 &, 964 &, 12828 \\
\hline
\end{tabular}

Sumber: Data diolah, 2020

Berdasarkan Tabel 4 didapatkan nilai Adjusted $R$ Square sebesar 0,964. Artinya sebesar 96,4 persen variasi tingkat pengangguran dijelaskan oleh variabel bebas dalam model, sedangkan sisanya 3,6 persen dijelaskan oleh variabel lain diluar penelitian.

\section{Uji Parsial}

Uji parsial bertujuan untuk mengetahui apakah secara parsial variabel independen berpengaruh signifikan terhadap variabel dependen. Uji parsial menggunakan uji $t$ sebagaimana diberikan pada Tabel 3:

Tabel 4. Estimasi Model

\begin{tabular}{|c|c|c|c|c|c|c|c|}
\hline \multirow{3}{*}{ Model } & \multicolumn{6}{|c|}{ Coefficients $^{\mathrm{a}}$} & \\
\hline & \multicolumn{2}{|c|}{$\begin{array}{l}\text { Unstandardized } \\
\text { Coefficients }\end{array}$} & \multirow{2}{*}{$\begin{array}{c}\begin{array}{c}\text { Standardize } \\
d \\
\text { Coefficients }\end{array} \\
\text { Beta }\end{array}$} & \multirow[t]{2}{*}{$t$} & \multirow[t]{2}{*}{ Sig. } & \multicolumn{2}{|c|}{ Collinearity Statistics } \\
\hline & B & Std. Error & & & & Tolerance & VIF \\
\hline${ }^{1}$ (Constant) & $28,128^{-}$ & 10,757 & & $-2,615$ & ,020 & & \\
\hline PE &,- 529 & 240 &,- 873 & $-2,203$ & 045 & ,936 & 1,069 \\
\hline LogUM & $-1,859$ & 864 & -,809 & $-2,152$ & 049, & 115 & 8,679 \\
\hline LogAK & 7,613 & 1,803 & ,740 & 4,223 & ,001 & ,113 & 8,817 \\
\hline
\end{tabular}

a. Dependent Variable: TPG

Sumber: Data diolah, 2020

\section{Variabel Pertumbuhan Ekonomi}

Nilai probabilita variabel pertumbuhan ekonomi sebesar 0,045. Dengan tingkat keyakinan $(\alpha=5 \%)$, nilai probabilita lebih kecil dari alpha $(0,045<0,05)$. Ho ditolak dan $\mathrm{Ha}$ diterima. Ini berarti bahwa pertumbuhan ekonomi berpengaruh signifikan terhadap tingkat pengangguran di Provinsi Jambi. 


\section{Variabel Upah Minimum}

Nilai probabilita variabel upah minimum sebesar 0,049, lebih kecil dari alpha 0,05. Ho ditolak dan Ha. Dengan demikian dapat disimpulkan bahwa upah minimum berpengaruh signifikan terhadap tingkat pengangguran di Provinsi Jambi.

\section{Variabel Angkatan Kerja}

Nilai probabilita untuk variabel angkatan kerja sebesar 0,001, lebih kecil dari alpha 0,05 Artinya Ho ditolak dan Ha diterima. Dapat disimpulkan bahwa angkatan kerja berpengaruh signifikan terhadap tingkat pengangguran di Provinsi Jambi.

\section{Implikasi Penelitian}

\section{Pengaruh Pertumbuhan Ekonomi Terhadap Tingkat Pengangguran}

Pertumbuhan ekonomi berpengaruh signifikan terhadap tingkat pengangguran, dengan nilai koefisien sebesar $-0,529$ hal ini berarti setiap terjadi peningkatan pertumbuhan ekonomi 1 persen maka rata-rata tingkat pengangguran di Provinsi Jambi periode 2001-2018 menurun sebesar - 0,529 persen dengan asumsi variabel bebas lainnya dalam keadaaan relatif atau tidak berubah. Temuan penelitian ini sejalan dengan penelitian Husain dkk (2010), Nurcholis (2014), Suhendra \& Wicaksono (2016), dan Sari (2010)

Peningkatan pertumbuhan ekonomi suatu negara akan meningkatkan penyerapan tenaga kerja, yang selanjutnya akan menurunkan pengangguran. Oleh karenanya percepatan pertumbuhan ekonomi merupakan salah satu upaya untuk mengatasi permasalahan pengangguran (Harfina, 2009).

Pengaruh Upah Minimum Terhadap Tingkat Pengangguran

Upah minimum berpengaruh signifikan terhadap tingkat pengangguran, dengan nilai koefisien sebesar $-1,859$. Hal ini berarti setiap terjadi peningkatan pertumbuhan ekonomi 1 persen maka rata-rata tingkat pengangguran di Provinsi Jambi periode 2001-2018 menurun sebesar -1,859 persen dengan asumsi variabel bebas lainnya dalam keadaaan relatif atau tidak berubah. Penelitian ini sejalan dengan temuan Nurcholis (2014), Suhendra \& Wicaksono (2016), dan Agustina (2010).

\section{Pengaruh Angkatan Kerja Terhadap Tingkat Pengangguran}

Berdasarkan hasil regresi diketahui bahwa angkatan kerja berpengaruh signifikan terhadap tingkat pengangguran, dengan nilai koefisien sebesar 0,355 hal ini berarti setiap peningkatan angkatan kerja sebesar 1 persen maka akan meningkatkan tingkat pengangguran sebesar 0,355 persen dengan asumsi variabel bebas lainnya dalam keadaaan relatif atau tidak berubah. Temuan penelitian ini sejalan dengan temuan Putri dkk (2017), Anggoro (2015) dan Lumi dkk (2021). Angkatan kerja berpengaruh signifikan terhadap tingkat pengangguran disebabkan oleh peningkatan angkatan kerja tidak diikuti oleh peningkatan kesempatan kerja dengan jumlah yang sama (Jumairi dkk, 2020). Angkatan kerja setiap tahun terus meningkat namun besarnya peningkatan angkatan kerja dominan dari penduduk pendidikan rendah sehingga sulit untuk mencari pekerjaan dan memperparah masalah pengangguran (Swarsih, dkk, 2020)

\section{Kesimpulan dan Saran}

\section{Kesimpulan}

Rata-rata tingkat tingkat pengangguran di Provinsi Jambi selama periode $2001-2018$ adalah 4,45 persen. Baik secara simultan maupun parsial, tingkat pengangguran di Provinsi Jambi dipengaruhi oleh pertumbuhan ekonomi, upah minimum, angkatan kerja. 


\section{Saran}

Pemerintah Provinsi Jambi seharusnya dapat mengatasi meningkatnya pengangguran melalui peningkatan program pelatihan dan pendidikan dengan tujuan pembentukan keterampilan. Tenaga kerja yang terampil memiliki kesempatan lebih besar untuk mendapatkan pekerjaan dibandingkan mereka yang tidak memiliki keterampilan. Peneliti selanjutnya yang berkaitan dengan judul penelitian ini agar diharapkan dapat menambah rentang waktu (time series) dan menambah variabel bebas agar hasil penelitian dapat lebih signifikan.

\section{Daftar Pustaka}

Agustina, M. (2010). Analisis tingkat pengangguran dan faktor-faktor yang mempengaruhinya di Kota Semarang. [skripsi]. Fakultas Ekonomi Universitas Diponegoro Semarang

Anggoro, M.H. (2015). Pengaruh Pertumbuhan Ekonomi dan Pertumbuhan Angkatan Kerja terhadap Tingkat Pengangguran di Kota Surabaya. Jurnal Pendidikan Ekonomi (JUPE), 3(3)

Gujarati, D. N., \& Porter, D. C. (2009). Basic econometrics. McGraw-Hill.

Harfina, D. (2009). Faktor-faktor yang memengaruhi pengangguran terselubung di Jawa Tengah, Jurnal Kependudukan Indonesia, 4(1), 15-32.

Hussain, T., Siddiqi, W. \& Iqbal, A.. (2010). A Coherent Relationship between Economic Growth and Unemployment: An Empirical Evidence from Pakistan. International Journal of Human and Social Sciences, 5(5), 1098 - 1105

Jumairi, J., Junaidi, Y., \& Junaidi, J. (2020). Faktor - faktor yang mempengaruhi lamanya mencari pekerjaan di Desa Betung Bedarah Timur Kecamatan Tebo Ilir. E-Jurnal Ekonomi Sumberdaya Dan Lingkungan, 9(3), 170-180. https://doi.org/10.22437/jels.v9i3.11959

Kaufman, B. E., \& Hotchkiss, J. L. (2003). The economics of labor markets. Thomson/SouthWestern.

Lumi, A.N.M., Walewangko, E.N. \& Lapian, A.L.C.P. (2021). Analisis Pengaruh Jumlah Angkatan Kerja Dan Indeks Pembangunan Manusia Terhadap Tingkat

Pengangguran Di Kota-Kota Provinsi Sulawesi Utara. Jurnal EMBA, 9(3), 162 - 172

Mankiw, N. G. (2003). Teori Makroekonomi edisi kelima. Erlangga.

Mankiw, N. G. (2006). Principles of Economics (Pengantar Ekonomi Makro) (C. Sungkono, Terj.) (Ed. 3). Salemba Empat.

Natsir, M. (2001). Metode Penelitian. Ghalia Indonesia.

Nurcholish, M. (2014). Analisis Pengaruh Pertumbuhan Ekonomi, Upah Minimum dan Indeks Pembangunan Manusia Terhadap Tingkat Pengangguran di Provinsi Jawa Timur Tahun 2008 - 2014. Jurnal Ekonomi Pembangunan, 12(1), 45 - 57

Oetomo, L., \& Silalahi, E. E. (2006). Analisis pengaruh upah terhadap pengangguran di DKI Jakarta tahun 1991-2003 [Skripsi]. Fakultas Ekonomi Universitas Atma Jaya. https://lib.atmajaya.ac.id/default.aspx?tabID=112\&src=k\&id=3886

Putri, D.N., Sudarti, S. \& Hadi, S. (2017). Analisis Pengaruh Pertumbuhan Ekonomi Dan Jumlah Angkatan Kerja Terhadap Jumlah Pengangguran Di Kota Batu. Jurnal Ilmu Ekonomi, 1(3), 270 - 281

Sari, A.K. (2012). Analisis Tingkat Pendidikan, Pertumbuhan Ekonomi, dan Upah Terhadap Pengangguran Terdidik di Sumatra Barat. Jurnal Ekonomi Pembangunan.

Suhendra, I \& Wicaksono, B.H. (2016) Tingkat Pendidikan, Upah, Inflasi, Dan Pertumbuhan Ekonomi Terhadap Pengangguran Di Indonesia. Jurnal Ekonomi-Qu, 6(1), 1 - 17 
Sukirno, S. (2013). Makroekonomi: Teori pengantar. PT. Raja Grafindo Persada.

Swarsih, C., Junaidi, J., \& Rosmeli, R. (2020). Pengaruh umur, pendidikan, upah, keterampilan, dan jenis kelamin terhadap lama mencari kerja bagi pekerja terdidik di Kota Jambi (studi kasus Kecamatan Kota Baru dan Telanaipura). E-Jurnal Ekonomi Sumberdaya Dan Lingkungan, 9(1), 1-12. https://doi.org/10.22437/jels.v9i1.11944

Todaro, M. P., \& Smith, S. C. (2006). Pembangunan Ekonomi. Erlangga.

Winarno, W. W.(2009). Analisis ekonometrika dan statistika dengan Eviews. UPP STIM YKPN.

(C) 2021 oleh penulis. Pemegang Lisensi JEA, Indonesia. Artikel ini merupakan artikel akses terbuka yang didistribusikan di bawah syarat dan ketentuan Lisensi Atribusi Creative Commons (CC BY-SA) (http://creativecommons.org/licenses/by/4.0/) 